\title{
Phytochemical and technological characterization of canistel dehydrated pulp: a new
}

\section{potential food ingredient}

Caracterização fitoquímica e tecnológica da polpa desidratada de canistel: um novo potencial ingrediente alimentar

Caracterización fitoquímica y tecnológica de la pulpa deshidratada de canistel: un nuevo ingrediente alimentario potencial

Received: 12/29/2020 | Reviewed: 01/02/2021 | Accept: 01/04/2021 | Published: 01/06/2021

Fernando Antônio Anjo ORCID: https://orcid.org/0000-0001-6886-0304 Universidade Estadual de Maringá, Brasil E-mail: fernandoaanjo@hotmail.com

Bianka Rocha Saraiva

ORCID: https://orcid.org/0000-0002-6575-9857 Universidade Estadual de Maringá, Brasil E-mail: bianka_saraiva@hotmail.com

Camilla Yara Langer Ogawa

ORCID: https://orcid.org/0000-0001-5818-4410 Universidade Estadual de Maringá, Brasil

E-mail: camyogawa@gmail.com

Ana Carolina Pelaes Vital

ORCID: https://orcid.org/0000-0002-6033-6898 Universidade Estadual de Maringá, Brasil

E-mail: ana_carolv@hotmail.com

Francielle Sato

ORCID: https://orcid.org/0000-0002-8273-2891 Universidade Estadual de Maringá, Brasil E-mail: fsatouem@gmail.com

Paula Toshimi Matumoto-Pintro

ORCID: https://orcid.org/0000-0002-9182-5758 Universidade Estadual de Maringá, Brasil E-mail: ptmpintro@uem.br

\begin{abstract}
Canistel (Pouteria campechiana (Kunth) Baehni) is a tropical fruit with a yellow pulp due to the presence of carotenoids, which may be interesting for application by the food industry. The aim of this research was to analyze the phytochemical and technological characteristic of dehydrated canistel pulp by thermal dehydration and freeze-drying techniques. Test for antioxidant activities (DPPH and ABTS radical scavenging; ferric reducing antioxidant power - FRAP), total polyphenols, flavonoids, carotenoids content (UV-Vis, FTIR and Raman spectroscopy), color, and hygroscopic properties were performed. The freeze-dried sample showed a higher carotenoids concentration, more intense coloring and better hydration properties than the thermally dehydrated sample. Functional groups such as water, carotenoids, primary and secondary amides, aldehydes groups, phenolic acids, aromatic rings, cellulose, polysaccharides and niacin were identified by FTIR in both samples. Ingredient obtained by freeze drying showed better technological characteristics, allowing its use by the food industry.
\end{abstract}

Keywords: Pouteria campechiana (Kunth) Baehni; Bioactive compounds; Carotenoids; Hygroscopic properties.

\section{Resumo}

Canistel (Pouteria campechiana (Kunth) Baehni) é uma fruta tropical de polpa amarela devido à presença de carotenoides, que pode ser de interesse para aplicação na indústria alimentícia. O objetivo desta pesquisa foi analisar as características fitoquímicas e tecnológicas da polpa de canistel desidratada por técnicas de desidratação térmica e liofilização. Os ensaios de atividades antioxidantes (radical DPPH e ABTS; atividade antioxidante pelo poder de redução do ferro - FRAP), teor de polifenóis totais flavonoides e carotenoides (Espectroscopia UV-Vis, FTIR e Raman), cor e propriedades higroscópicas foram realizados. A amostra liofilizada apresentou maior concentração de carotenoides, coloração mais intensa e melhores propriedades de hidratação que a amostra desidratada termicamente. Grupos funcionais pertencentes a água, carotenoides, amidas primárias e secundárias, grupos aldeídos, ácidos fenólicos, anéis aromáticos, celulose, polissacarídeos e niacina foram identificados por FTIR em ambas as amostras. O ingrediente obtido por liofilização apresentou melhores características tecnológicas, permitindo seu uso pela indústria alimentícia. 
Palavras-chave: Pouteria campechiana (Kunth) Baehni; Compostos bioativos; Carotenoides; Propriedades higroscópicas.

\section{Resumen}

Canistel (Pouteria campechiana (Kunth) Baehni) es una fruta tropical de pulpa amarilla debido a la presencia de carotenoides, que puede ser de interés para aplicación en la industria alimentaria. El objetivo de esta investigación fue analizar las características fitoquímicas y tecnológicas de la pulpa de canistel deshidratada mediante técnicas de deshidratación térmica y liofilización. Se realizaron pruebas de actividad antioxidante (DPPH y ABTS; poder antioxidante reductor férrico - FRAP), contenido total de polifenoles, flavonoides, carotenoides (espectroscopía UVVis, FTIR y Raman), color y propiedades higroscópicas. La muestra liofilizada mostró mayor concentración de carotenoides, coloración más intensa y mejores propiedades de hidratación que la muestra deshidratada térmicamente. Se identificaron mediante FTIR grupos funcionales pertenecientes al agua, carotenoides, aminas primarias y secundarias, grupos aldehídos, ácidos fenólicos, anillos aromáticos, celulosa, polisacáridos y niacina en ambas muestras. El ingrediente obtenido por la liofilización mostró mejores características tecnológicas, permitiendo su uso por la industria alimentaria.

Palabras clave: Pouteria campechiana (Kunth) baehni; Compuestos bioactivos; Carotenoides; Propiedades higroscópicas.

\section{Introduction}

Exotic fruits consumption has been increasing significantly in the last few years. These fruits can also be used by food industry as ingredients for natural additives development such as antioxidants, antimicrobials, dyes, flavorings, thickening agents, among others (Ayala-Zavala et al., 2011). An increase in the use of exotic fruits can stimulate smallholder incomes, raise industrial profitability, and meet consumers demands who are concerned about chemical presence in food and are looking for healthier foods.

Canistel (Pouteria campechiana (Kunth) Baehni) is a tropical fruit from Sapotaceae family and native from Mexico. Its fruits are oval in shape, have 1 to 4 seeds, thin and smooth peel, with dense, creamy flesh and intense yellow color (Pushpakumara, 2007). It is rich in carotenoids from xanthophylls group, presents violaxanthin, neoxanthin, zeaxanthin, $\beta$ cryptoxanthin and other carotenoids (de Lanerolle et al., 2008; Murillo et al., 2010).

Canistel chemical composition presents carbohydrates, proteins, lipids and a high amount of water (> 60\%). Its fruits are big, with a soft texture and climacteric. These characteristics make the canistel fruits perishable and remain viable for a maximum of 10 days under ambient conditions (Pushpakumara, 2007). Conservation techniques can be adopted aiming to increase fruit availability, avoiding microbial, enzymatic, chemical and physical changes, maintaining their nutrients and their sensorial characteristics for a longer time.

The oldest technique used in food preservation, the dehydration, is based on water activity reduction. Thermal dehydration may remove water; however, it causes loss of taste, aroma and/or functional compounds, being a problem in terms of quality. Freeze drying, keeps the nutrients and sensorial characteristics stable (Almeida et al., 2020; Wojdyło et al., 2014). Thus, the objective of this study was to evaluate the phytochemical and technological characteristics of canistel powder (thermal dehydration and freeze-dried) for a potential use in food industry.

\section{Methodology}

\subsection{Material}

Canistel fruits were acquired at the Experimental Station of Citriculture from Bebedouro (Bebedouro, São Paulo, Brazil) $\left(20^{\circ} 53 ' \mathrm{~S}, 48^{\circ} 28^{\prime} \mathrm{W}\right)$. Folin-Ciocalteu reagent, gallic acid, 2,2'-azino-bis-3-ethyl benzothiazoline-6-sulfonic acid (ABTS), 2,2diphenyl-1-picrylhydrazyl radical (DPPH), quercetin, methyl alcohol, hydrochloric acid, trichloroacetic acid, phosphate buffer, sodium carbonate, potassium persulphate and $\beta$-carotene (purity $\geq 95 \%$, synthetic, type II and crystalline) from Sigma Aldrich (USA). Aluminum chloride, potassium ferricyanide, ferric chloride, petroleum ether and acetone were analytical grade. 


\subsection{Preparation of the raw material}

Canistel fruits were washed in running water, sanitized with sodium hypochlorite (200ppm/10min) and washed with distilled water. Then, were peeled, sliced and dehydrated by two different techniques, with freeze-dryer (FD), where the pulp was frozen with liquid nitrogen and lyophilized and with an oven with air circulation and temperature of $70^{\circ} \mathrm{C}$ for 7 hours (TD). After freeze-drying and dehydration, pulps were crushed and the granulometry standardized at 60 mesh.

\subsection{Fourier transform infrared spectroscopy - FTIR}

An infrared spectrometer with Fourier transform (FTIR) (model Vertex 70v, Bruker, Germany) was used attached to an attenuated total reflectance accessory (ATR) (model Platinum, Bruker, Germany) for dehydrated pulp and fresh canistel (FP) measurements. Samples were positioned and primed on ATR diamond crystal so that all the diamond was in contact with them during the measurements. Each spectrum obtained is an average at 128 scans, with a spectral resolution at $4 \mathrm{~cm}^{-1}$. The range used for analysis was 4000 to $400 \mathrm{~cm}^{-1}$.

\subsection{Raman spectroscopy}

FT-Raman spectra were recorded using a Fourier transform spectrometer attached to the Raman spectroscopy. module (FT-Raman) (model, Vertex 70v - RAM II, Bruker, Germany) was used. The excitation source used was an Nd-Yag laser, at $1064 \mathrm{~nm}$ and $150 \mathrm{~mW}$ nominal power. Spectral data from FD and TD and $\beta$-carotene were 128 scans with a spectral resolution of $4 \mathrm{~cm}^{-1}$ in the range at 4000 to $400 \mathrm{~cm}^{-1}$ with a nominal laser power at $150 \mathrm{~mW}$.

\subsection{Bioactive compounds}

Total polyphenols compounds were determined using a methanolic solution (1:10 w/v) mixed with FD and TD. An aliquot of $125 \mu \mathrm{L}$ of the extract was added with $125 \mu \mathrm{L}$ of Folin-Ciocalteu reagent $(50 \%)$ and $2250 \mu \mathrm{L}$ of sodium carbonate (28 g. $\left.\mathrm{L}^{-1}\right)$. The samples were incubated in the dark at $25^{\circ} \mathrm{C}$ for $30 \mathrm{~min}$ and thereafter the absorbance was determined at $725 \mathrm{~nm}$. The results were expressed by standard curve $\left(y=181.67 x+6.9821 ; \mathrm{R}^{2}=0.9988\right)$ of gallic acid $(0.1 \%)$ ranging from 0 to $300 \mathrm{mg} . \mathrm{L}^{-}$ ${ }^{1}$ (Singleton et al., 1965).

Total flavonoid compounds were analyzed using the methanolic extract (1:10 w/v) from FD and TD. An aliquot (300 $\mu \mathrm{L}$ ) was added with $150 \mu \mathrm{L}$ of $\mathrm{AlCl}_{3}\left(50 \mathrm{~g} . \mathrm{L}^{-1}\right)$ and $2250 \mu \mathrm{L}$ of methanol $100 \%$. The absorbance was determined at $425 \mathrm{~nm}$ and the results obtained were expressed by standard curve $\left(y=110.96 \mathrm{x}+4.2199 ; \mathrm{R}^{2}=0.9932\right)$ of quercetin $(0.1 \%)$ ranging from 0 to $300 \mathrm{mg} . \mathrm{L}^{-1}$ (Buriol et al., 2009).

Bioactivity compounds were identified and quantified using high performance liquid chromatograph (Alliance Waters e2695, Mildford, USA), equipped with separation module, quaternary pump and photodiode detector. The separation was obtained with reverse phase -C18 column (ACE3 C18- AE, $150 \mathrm{~mm}$ x $4.6 \mathrm{~mm}$ x $5 \mu \mathrm{m}$ ). The sample or standard $(10 \mu \mathrm{L})$ was separated following the elution conditions: $3 \%$ aqueous acetic acid solution (A) and methanol (B) at $1 \mathrm{~mL} / \mathrm{min}$. Initially, the elution was composed of 100\% A and held for $1 \mathrm{~min}$, followed by a linear increase to $63 \% \mathrm{~B}$ in $27 \mathrm{~min}$, and then returned to the initial condition (Ma et al., 2004). Detection of compounds was performed between $370 \mathrm{~nm}$ and identified by comparison to UV spectrum of commercial standards (gallic acid and quercetin).

Total carotenoids were extracted using acetone and petroleum ether (Rodriguez-Amaya \& Kimura, 2004). The treatments samples $(1 \mathrm{~g})$ were macerated with acetone, filtered, and solid retained underwent successive extractions until there was no more perception of the color. Filtrate was collected quantitatively into a separatory funnel already containing $30 \mathrm{~mL}$ of petroleum ether. Distilled water was slowly added to the wash until the aqueous phase was clear and then discarded. Ethereal solution was transferred and elevated with petroleum ether in a $50 \mathrm{~mL}$ volumetric flask, the absorbance reading was done in a 
spectrophotometer at $450 \mathrm{~nm}$. The total carotenoid content was calculated by Equation 1 .

Total carotenoids $\left(\mathrm{mg} \cdot \mathrm{g}^{-1}\right)=\frac{\mathrm{abs} * \mathrm{v} * 10}{\mathrm{sm} * \varepsilon}$

abs: Absorbance

v: Final volume

sm: Sample mass

$\varepsilon: 2592$ (Absorption coefficient of $\beta$-carotene in petroleum ether)

\subsection{Antioxidant activity}

DPPH assay was performed with methanolic solution $150 \mu \mathrm{L}(1: 10 \mathrm{w} / \mathrm{v})$ of FD and TD which was mixed with $2850 \mu \mathrm{L}$ of DPPH solution in methanol $\left(0.00006 \mathrm{~mol} . \mathrm{L}^{-1}\right)$. Samples were incubated for $30 \mathrm{~min}$ in the dark and were measured at $515 \mathrm{~nm}$ and the percentage of antioxidant activity was calculated (Brand-Williams et al., 1995).

Regarding ABTS assay, the ABTS ${ }^{+}$was generated by the reaction of 0.007 mol.L $\mathrm{L}^{-1}$ ABTS with 0.14 mol. $\mathrm{L}^{-1}$ potassium persulfate. ABTS was incubated in the dark at $25{ }^{\circ} \mathrm{C}$ for $16 \mathrm{~h}$. The ABTS activated radical was diluted with methanol until absorbance of 0.70 . Methanolic extract $40 \mu \mathrm{L}(1: 10 \mathrm{w} / \mathrm{v})$ of FD and TD were mixed with $1960 \mu \mathrm{L}$ of ABTS solution. Absorbance was recorded after $6 \mathrm{~min}$ at $734 \mathrm{~nm}$ and the percentage of antioxidant activity was calculated (Rufino et al., 2010).

The ferric reducing antioxidant power (FRAP) was determined in the methanolic extract of FD and TD. An aliquot (250 $\mu \mathrm{L})$ of extract was mixed with 0.5 mol.L $\mathrm{L}^{-1}$ sodium phosphate buffer $\mathrm{pH} 7.0(1250 \mu \mathrm{L}), 1 \%$ potassium ferricyanide $(1250 \mu \mathrm{L})$ and incubated at $50{ }^{\circ} \mathrm{C}$ for $20 \mathrm{~min}$. After trichloroacetic acid (10\%) (1250 $\mathrm{LL}$ ) was added and centrifuged at $3000 \mathrm{rpm}$ for 10 min. The supernatant $(2500 \mu \mathrm{L})$ was mixed with $0.1 \%$ ferric chloride $(500 \mu \mathrm{L})$ and the absorbance was measured at $700 \mathrm{~nm}$. The results obtained were expressed according to the standard curve $\left(y=231.99 x+24.726 ; \mathrm{R}^{2}=0.9861\right)$ of gallic acid $(0.01 \%)$ ranging from 0 to $300 \mathrm{mg} . \mathrm{L}^{-1}$ (Zhu et al., 2002).

\subsection{Technological characteristics}

FD and TD had their color evaluated by CIELAB color scale, measuring the parameters $L^{*}, a^{*}$ and $b^{*}$. The $L^{*} a^{*} b^{*}$ color space was modeled after a color-opponent theory stating that two colors cannot be red and green at the same time or yellow and blue at the same time. The $\mathrm{L}^{*}$ indicates lightness $(100=$ white and $0=$ black $), \mathrm{a}^{*}$ is the red/green coordinate $\left(\mathrm{a}^{*}(+)\right.$ indicates red and $a^{*}(-)$ indicates green), and $b^{*}$ is the yellow/blue coordinate $\left(b^{*}(+)\right.$ indicates yellow and $b^{*}(-)$ indicates blue

Water absorption index (WAI) and water solubility index (WSI) were determined with $2.5 \mathrm{~g}$ of FD and TD diluted in $30 \mathrm{~mL}$ of distilled water. Samples were shaken on vortex for $1 \mathrm{~min}$, shaking in tube homogenizer for $30 \mathrm{~min}$ and centrifuged at $4000 \mathrm{rpm}$ for $10 \mathrm{~min}$. Supernatant was heated at $105{ }^{\circ} \mathrm{C}$ for $12 \mathrm{~h}$. The evaporation residue was weighed and the percentage of WAI and WSI were calculated (Anderson et al., 1970).

Oil absorption capacity (OAC) of FD and TD was tested in soybean oil. $0.5 \mathrm{~g}$ of samples were homogenized with $3 \mathrm{~g}$ of oil in a graduated centrifuge tube for $1 \mathrm{~min}$ in a vortex shaker, the tube was allowed to stand still for $30 \mathrm{~min}$ at $25^{\circ} \mathrm{C}$ and the samples were centrifuged for $30 \mathrm{~min}$ at $3270 \mathrm{rpm}$. Supernatant was removed, the precipitate was weighed and the percentage of OAC was calculated (Lin, Humbert, \& Sosulski, 1974).

\subsection{Statistical analyses}

All determinations were performed with three replicates expressed in mean and standard deviation. The data were submitted to analysis of variance and, when differences were found $(\mathrm{p} \leq 0.05)$, the means were compared by Tukey test, at the 5\% probability level, using Statistical Analysis System (SAS) 9.1 software package (SAS Institute Inc., Cary, NC, USA). 


\section{Results and Discussion}

\subsection{Fourier transform infrared and Raman spectroscopy}

The infrared spectra obtained are shown in Figure 1-A. The region at $3500-3000 \mathrm{~cm}^{-1}$ is attributed to $\mathrm{OH}$ groups vibrational stretching to be involved in hydrogen bonds from water molecules and NH were from primary amide stretching (Olsson \& Salmén, 2004; Sunila et al., 2016). Bands centered at 2923 and $2854 \mathrm{~cm}^{-1}$ refer to $\mathrm{CH}_{2}$ asymmetric and symmetrical stretch that can be derived from the carotenoids present in the pulp (Heredia-Guerrero et al., 2014). The spectrum presented band at $1730 \mathrm{~cm}^{-1}$ assigned to $\mathrm{C}=\mathrm{O}$ groups stretching of aldehyde (Sunila et al., 2016). The bands between 1630 and $1600 \mathrm{~cm}^{-1}$ are attributed to $\mathrm{C}=\mathrm{C}$ stretch from phenolic acids and $\mathrm{C}-\mathrm{C}$ phenol aromatic rings (Heredia-Guerrero et al., 2014; Iqbal et al., 2009). The $\mathrm{C}=\mathrm{O}$ stretch from primary amides and $\mathrm{NH}$ angular deformation of the secondary amides are evidenced in the spectrum at 1650 and $1545 \mathrm{~cm}^{-1}$, respectively (Stehfest et al., 2005). The band at $1247 \mathrm{~cm}^{-1}$ is attributed to the angular deformation of C-OC, characteristic of cellulose chains (Mothé \& De Miranda, 2009). The region comprised between $1200-900 \mathrm{~cm}^{-1}$ is attributed to polysaccharides (Posé et al., 2012). All bands were found in both treatments.

Figure 1. A) Canistel pulp infrared spectra. B) Enlargement of bands due to water molecules. C) Lower band intensity caused by dehydration.
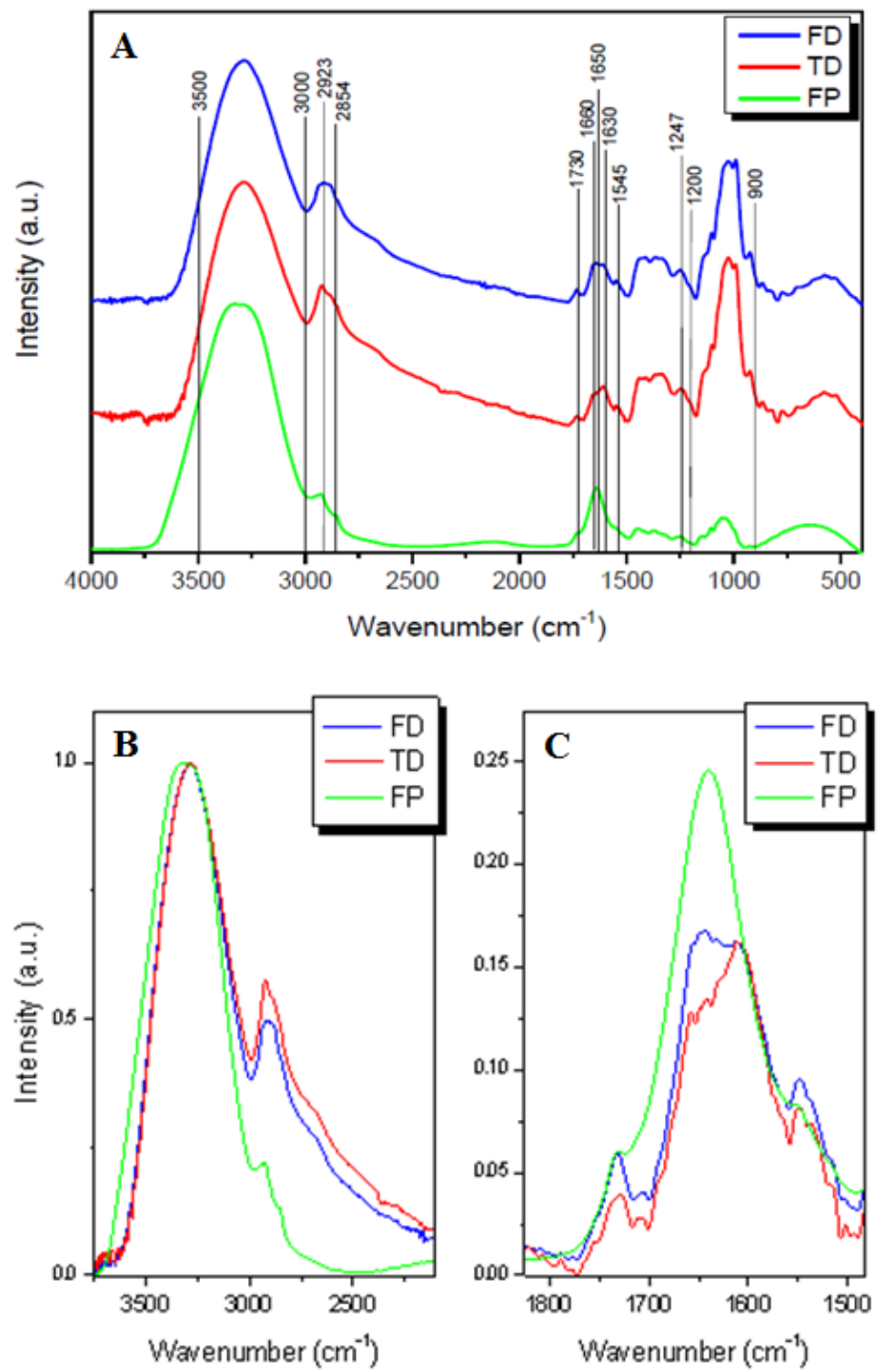

FD: freeze-dried; TD: thermal dehydration; FP: fresh pulp. Source: Authors. 
Dehydration techniques influenced on infrared spectra. Figure 1-B and 1-C shows some differences observed in FD, TD and FP spectrum. A band enlargement at 3600-3000 $\mathrm{cm}^{-1}$ and an increase in band intensity at $1645 \mathrm{~cm}^{-1}$ in FP spectrum, these bands correspond to $\mathrm{OH}$ stretching and $\mathrm{HOH}$ groups, bands characteristics of water molecules (Olsson \& Salmén, 2004; Stuart, 2004). In FD and TD, a band was observed at $1610 \mathrm{~cm}^{-1}$, with less intensity than in FP. This band is characteristic of amide functional group present in niacin molecules (vitamin B3) (Wojciechowski et al., 1998). This lower intensity was caused by dehydration. FD and DT have no difference in band intensity because niacin is a vitamin resistant to heat, light and oxygen (Schwartz et al., 2007).

Samples were evaluated by Raman spectroscopy and compared to a $\beta$-carotene standard. Figure 2 shows that $\beta$-carotene vibrational modes were observed at $\sim 1515, \sim 1159, \sim 1011 \mathrm{~cm}^{-1}$, which refers to $\mathrm{C}=\mathrm{C}, \mathrm{C}-\mathrm{C}$ stretches and angular rocking motions from $\mathrm{CH}_{3}$, respectively (Baranska et al., 2006; Darvin et al., 2006). The same vibrational modes were identified in PF, FD and $\mathrm{TD}$, evidencing the presence of carotenoid $\beta$-carotene even after dehydration processes.

Figure 2. Raman spectra from FD, TD and $\beta$-carotene standard samples.

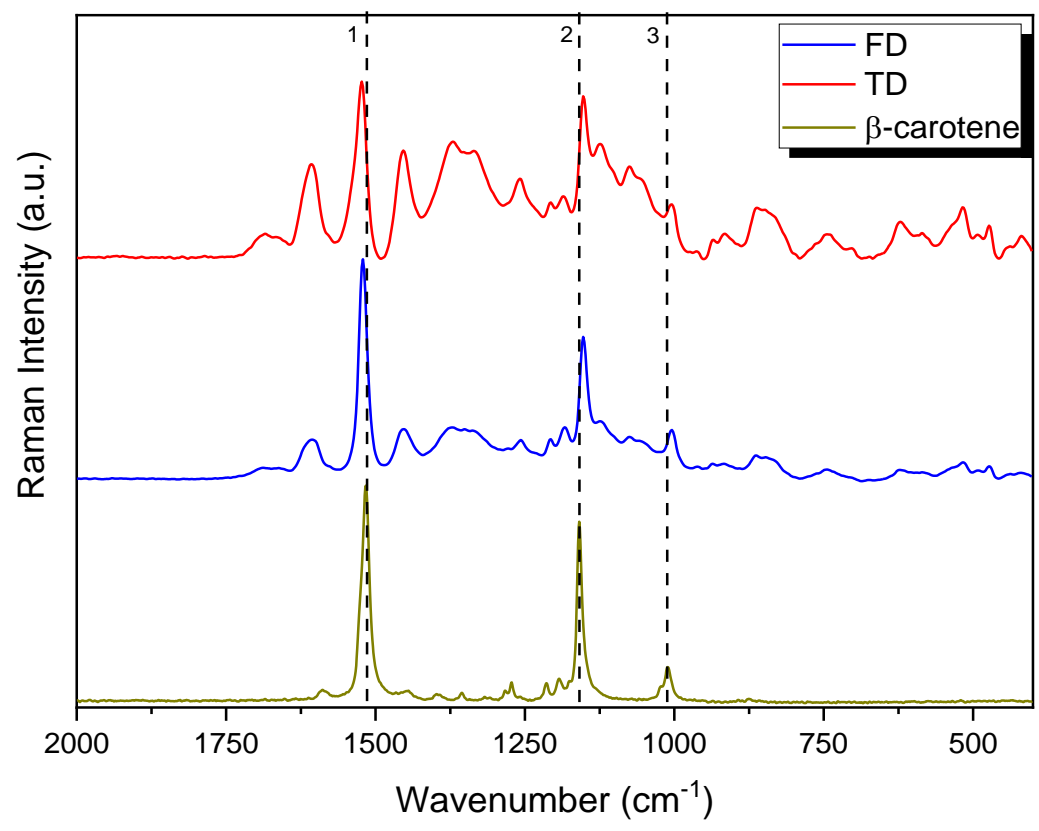

FD: freeze-dried and TD: thermal dehydration. Wavenumber: 1) $\sim 1515 \mathrm{~cm}^{-1}$; 2) $\sim 1159 \mathrm{~cm}^{-1}$; 3) $\sim 1011 \mathrm{~cm}^{-1}$. Source: Authors.

\subsection{Bioactive compounds}

The total polyphenols compounds (TPC) were similar for FD and TD (Table 1 and Figure 3). Other studies showed a TPC variation in canistel pulp samples, amounts at 115 mgGAE.g ${ }^{-1}$ (Aseervatham et al., 2014), 12.09 mgGAE.g-1 (Kong et al., 2013), 0.016 mgGAE.g ${ }^{-1}$ (Ma et al., 2004) were found. Polyphenols are compounds that contain one or more hydrocarbon groups attached to an aromatic ring. This group of compounds includes simple phenols, phenolic acids, stilbenes, flavonoids and highly polymerized compounds such as lignin and tannins. They act as antioxidants, eliminating oxygen radicals (Ainsworth \& Gillespie, 2007).

FD and TD differ in flavonoids quantity (Table 1), this difference can be attributed to anthoxanthins presence. These compounds when submitted to heat treatment can give rise to chalcones, changing the color and influencing the analysis (Schwartz et al., 2007). The difference between the flavonoids amounts may also be attributed to the heat action during the thermal dehydration; heat can cause darkening reactions (Maillard reaction and caramelization), which can lead to the formation 
of melanoidins, influencing the flavonoids content results. The chromatogram (Figure 3) shows that there is no difference in the intensity of the optimized peaks 1 (gallic acid) and 2 (quercetin) showing a correlation with the TPC and TF data in Table 1. Both treatments evaluated in this study had lower flavonoids amounts than dehydrated canistel pulp from India (70 mgQE.g $\left.{ }^{-1}\right)$ (Aseervatham et al., 2014). Climatic factors and physiological conditions of the plant may justify the difference between the amounts of flavonoids obtained. Different analytical conditions such as the methods used to obtain the extract and the applied methodology can also contribute to different results (Kalt, 2005).

Table 1. Bioactive compounds and technological characteristics of dehydrated canistel pulp.

\begin{tabular}{|c|c|c|}
\hline & FD & TD \\
\hline \multicolumn{3}{|l|}{ Bioactive compounds } \\
\hline TPC (mgGAE.g $\left.{ }^{-1}\right)$ & $4.56 \pm 0.27^{a}$ & $5.19 \pm 0.39^{\circ}$ \\
\hline $\mathrm{TF}\left(\mathrm{mgQE} \cdot \mathrm{g}^{-1}\right)$ & $0.38 \pm 0.04^{b}$ & $0.68 \pm 0.04^{c}$ \\
\hline $\mathrm{TC}\left(\mathrm{mg} \beta\right.$-carotene. $\left.\mathrm{g}^{-1}\right)$ & $1.00 \pm 0.07^{a}$ & $0.88 \pm 0.03^{b}$ \\
\hline DPPH $(\%)$ & $95.09 \pm 0.27^{a}$ & $94.27 \pm 0.23^{\circ}$ \\
\hline $\operatorname{ABTS}(\%)$ & $59.07 \pm 1.84^{a}$ & $57.52 \pm 0.01^{\circ}$ \\
\hline FRAP $\left(m g G A E . g^{-1}\right)$ & $1.74 \pm 0.16^{a}$ & $2.11 \pm 0.16^{c}$ \\
\hline \multicolumn{3}{|c|}{ Technological characteristics } \\
\hline $\mathrm{L}^{*}$ & $81.81 \pm 0.11^{a}$ & $73.81 \pm 0.80^{b}$ \\
\hline$a^{*}$ & $12.59 \pm 0.05^{a}$ & $7.09 \pm 0.34^{b}$ \\
\hline$b^{*}$ & $66.21 \pm 0.26^{a}$ & $36.91 \pm 0.84^{b}$ \\
\hline WAI $(\%)$ & $3.96 \pm 0.04^{a}$ & $1.96 \pm 0.08^{b}$ \\
\hline WSI (\%) & $49.94 \pm 0.14^{a}$ & $46.61 \pm 0.63^{b}$ \\
\hline $\mathrm{OAC}(\%)$ & $147.10 \pm 0.96^{a}$ & $130.98 \pm 2.25^{b}$ \\
\hline
\end{tabular}

FD: freeze-dried; TD: thermal dehydration; TPC: Total phenolic compounds; TF: Total flavonoid compounds; TC: Total carotenoids; DPPH: DPPH radical scavenging capacity; ABTS: ABTS radical scavenging capacity; FRAP: Ferric ion reducing power. WAI: water absorption index; WSI: water solubility index; OAC: oil absorption capacity. $\mathrm{L}^{*}: 100=$ white and $0=$ black; $\mathrm{a}^{*}$ : a $(+)$ indicates red and a $(-)$ indicates green; $b^{*}: b(+)$ indicates yellow and $b(-)$ indicates blue. Means in the same line followed by distinct letters are different $(P<0.05)$.

Source: Authors.

Figure 3. Chromatographic profiles (HPLC) of freeze-dried (FD) and thermal dehydration (TD) canistel pulp at $370 \mathrm{~nm}$.

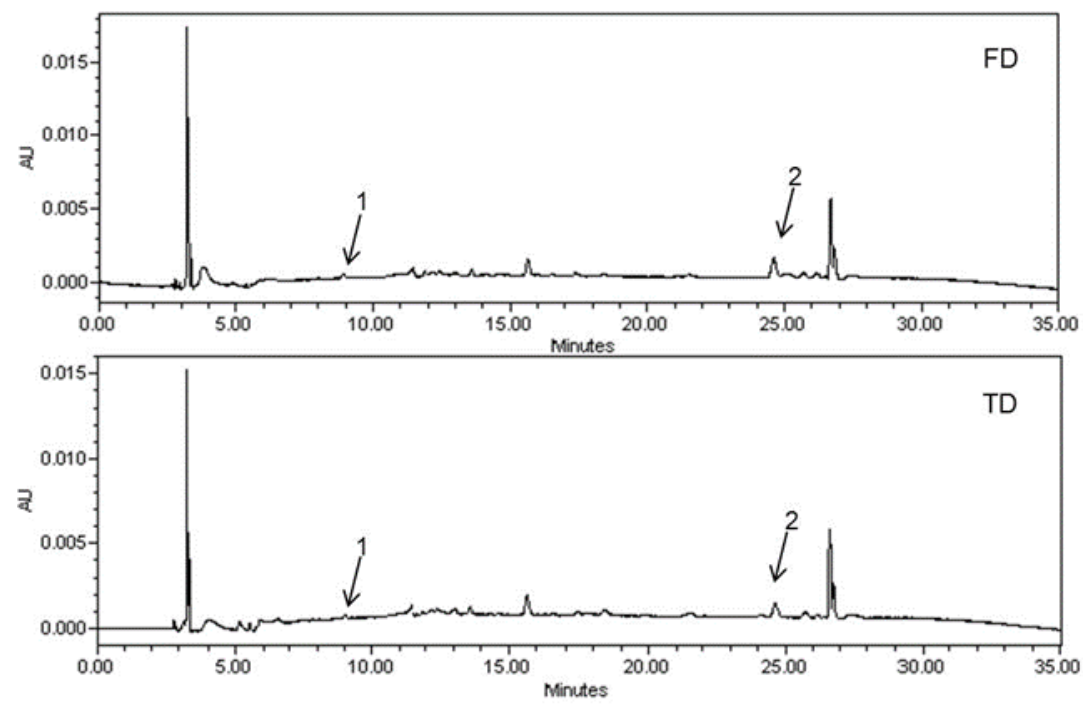

1 - Gallic acid; 2 - Quercetin. Source: Authors.

Carotenoids contribute to yellow color of the fruit. DT had lower $\beta$-carotene than FD, this result can also be observed through the spectrophotometric analyzes of FTIR and Raman. As shown in Figure 1-A and Figure 2, FDF signal strength is larger than DT. This difference in carotenoids content between DT and FD is explained by sensitivity of these compounds when 
exposed to temperature and oxygen for a long period, under these conditions, carotenoids are easily oxidized.

Canistel is a natural carotenoids source, as violaxanthin, neoxanthin, zeaxanthin, $\beta$-cryptoxanthin), $\alpha$-carotene, $\beta$ carotene and phytofluene (de Lanerolle et al., 2008); FD sample presented a higher content than fruits like Malpighia glabra (22 $\left.\mu \mathrm{g} \cdot \mathrm{g}^{-1}\right)$, Mangifera indica $\left(15 \mu \mathrm{g} \cdot \mathrm{g}^{-1}\right)$, Carica papaya $\left(1,2 \mu \mathrm{g} \cdot \mathrm{g}^{-1}\right)$ and Pidium guajava $\left(12 \mu \mathrm{g} \cdot \mathrm{g}^{-1}\right)$ (Rodrigues-Amaya et al., 2008).

\subsection{Antioxidant activity}

The dehydration techniques did not influence antioxidant activities (DPPH, ABTS and FRAP) and total polyphenols of canistel pulp (Table 1). A lower antioxidant activity was observed in ABTS assay compared to the DPPH assay (Table 1). Different methods for determining the antioxidant activity are used because the bioactive compounds can act by different mechanisms, either by reactions involving electron transfer processes (ABTS) or reactions involving hydrogen atom transfer (DPPH) (Gülçin, 2010).

This difference in antioxidant activity between the tests is due to reaction mechanism, which depends on type of reactive radical present in the extract and the solvent used in the extraction. In this study, solvent (methanol) used in the bioactive compounds' extraction is characterized as a polar solvent. In this type of solvents, carotenoids can remove the peroxyl radicals (ROO*) by addition or hydrogen extraction and electron transfer, depending on the free radical with which the carotenoid reacted (El-Agamey \& McGarvey, 2016). Therefore, it can be stated that reaction mechanism used by carotenoids present in methanolic extracts predominates the hydrogen atoms transfer (greater antioxidant activity by DPPH assay - Table 1).

The ferric reducing antioxidant power (FRAP) evaluates the chelating ability of some compounds. Both treatments showed no difference in antioxidant activity by FRAP assay. Aseervatham et al., (2014) showed that canistel has a higher ferric ion reduction power than butylated hydroxytoluene (BHT), an antioxidant widely used in the food industry.

Canistel contains different bioactive compounds, which have different chemical structures/functional groups, such as: $\mathrm{OH}$, - $\mathrm{SH}$, - $\mathrm{COOH},-\mathrm{H}_{2} \mathrm{PO}_{3}, \mathrm{C}=\mathrm{O},-\mathrm{NR}_{2},-\mathrm{S}$ - and -O-, these functional groups allow the compounds exhibit metal chelating activity. Iron is found in foods in the form of ferric $\left(\mathrm{Fe}^{3+}\right)$ and characterized by being an efficient pro-oxidant. When the iron ion is chelated, the antioxidant effects retard the oxidation catalyzed by metal, pro-oxidant properties are lost and diseases induced by oxidative stress can be prevented (Gülçin, 2010).

\subsection{Technological characteristics}

FD and TD color are shown in Table 1. TD had lower L*, $\mathrm{a}^{*}$ and $\mathrm{b}^{*}$ values than FD. Dehydration techniques that use heat can alter the physical-chemical characteristics of the raw material. Exposure to heat may lead to protein denaturation, enzymatic and non-enzymatic darkening reactions, texture changes, lipid oxidation, loss vitamins, bioactive compounds and especially pigments such as carotenoids. The heat influence on these compounds can be seen in Table 1 and in FTIR spectra (Figure 1). Carotenoids molecular structure has a large amount of unsaturation, which leads them to oxidize easily in the heat presence, air, light and acid. During oxidation process, the carotenoids color is degraded (Schwartz et al., 2007).

Fruit ripening has a direct influence on fruit color, when immature had a predominance of green color, due to the chlorophyll presence, which is in colloidal suspension associated with other substances, such as carotenoids. The bonds between these pigments (chlorophyll and carotenoids) are weak. During maturation, chlorophyll is degraded, green color disappears, carotenoid synthesis increases and consequently the fruit characteristic color becomes visible (Schwartz et al., 2007). When green color disappears, lightness increases and carotenoids (characteristic pigments of yellow and red color) are synthesized with greater speed and become more visible ( $\mathrm{a}^{*}$ and $\mathrm{b}^{*}$ become positive).

Hygroscopic characteristics, water absorption index (WAI), water solubility index (WSI) and oil absorption capacity (OAC) of FD and TD are presented in Table 1. FD and TD had differences in all hygroscopic properties analyzes, TD presented 
lower WAI, WSI and OAC than FD. Hot air convection dehydration promotes changes in physical properties, and consequently in hydration properties (Cadden, 1987). A higher OAC of FD is also related to its carotenoid's quantity, which are soluble in oil. TD presented smaller carotenoids quantities (Table 1). The heat effect on TD can be observed in Figure 1, carotenoids were degraded, due to its sensibility to heat, influencing in the OAC (Schwartz et al., 2007).

Hydration properties may reveal structural differences in the sample that affect its ability to absorb water and organic compounds. This parameter is technologically important, for processing and consequent incorporation of new ingredients into food formulations (Kaur \& Singh, 2005). WAI is related to -OH groups availability in water molecules binding (Colonna et al., 1984); WSI reflects the material degradation during dehydration, which influences its functionality (Guillon \& Champ, 2000) and the OAC indicates the sample ability to bind to water and other molecules impacting the texture and functionality of products (Kaur \& Singh, 2005). As shown in Table 1, FD has better hydration properties than TD, so it is an ingredient that can be incorporated more easily into food preparations.

\section{Conclusion}

The dehydration techniques did not influence antioxidant activities (DPPH, ABTS and FRAP) and total polyphenols of canistel pulp. The freeze-dried sample showed a higher carotenoids concentration, more intense coloring and better hydration properties than the thermally dehydrated sample. Functional groups belonging to water, carotenoids, primary and secondary amides, aldehyde groups, phenolic acids, aromatic rings, cellulose, polysaccharides and niacin were identified by FTIR in both samples. The dehydrated ingredient by freeze-dryer technique produced an ingredient with technological characteristics suitable for processing, allowing its use by the food industry.

\section{Acknowledgments}

We thank the Coordination for the Improvement of High Education Personnel Foundation (CAPES) for their financial support and Experimental Station of Citriculture from Bebedouro (Bebedouro, Sao Paulo, Brazil) for providing the canistel.

\section{References}

Ainsworth, E. A., \& Gillespie, K. M. (2007). Estimation of total phenolic content and other oxidation substrates in plant tissues using Folin-Ciocalteu reagent. Nature Protocols, 2(4), 875-877. https://doi.org/10.1038/nprot.2007.102.

Almeida, R. L., Santos, N. C., Pereira, T. dos S., Silva, V. M. de alcântara, Cabral, M. B., Barros, E. R., \& Silva, L. R. I. da. (2020). Determinação de compostos bioativos e composição físico-química da farinha da casca de jabuticaba obtida por secagem convectiva e liofilização. Research, Society and Development, 9(1), e157911876. https://doi.org/10.33448/rsd-v9i1.1876.

Anderson, R. A., Conway, H. F., \& Peplinski, A. J. (1970). Gelatinization of Corn Grits by Roll Cooking, Extrusion Cooking and Steaming. Starch - Stärke, 22(4), 130-135. https://doi.org/10.1002/star.19700220408.

Aseervatham, G. S. B., Sivasudha, T., Sasikumar, J. M., Christabel, P. H., Jeyadevi, R., \& Ananth, D. A. (2014). Antioxidant and hepatoprotective potential of Pouteria campechiana on acetaminophen-induced hepatic toxicity in rats. Journal of Physiology and Biochemistry, 70(1), 1-14. https://doi.org/10.1007/s13105013-0274-3.

Ayala-Zavala, J. F., Vega-Vega, V., Rosas-Domínguez, C., Palafox-Carlos, H., Villa-Rodriguez, J. A., Siddiqui, M. W., Dávila-Aviña, J. E., \& GonzálezAguilar, G. A. (2011). Agro-industrial potential of exotic fruit byproducts as a source of food additives. Food Research International, 44(7), 1866-1874. https://doi.org/10.1016/j.foodres.2011.02.021.

Baranska, M., Schütze, W., \& Schulz, H. (2006). Determination of lycopene and $\beta$-carotene content in tomato fruits and related products: Comparison of FTraman, ATR-IR, and NIR spectroscopy. Analytical Chemistry, 78(24), 8456-8461. https://doi.org/10.1021/ac061220j.

Brand-Williams, W., Cuvelier, M. E., \& Berset, C. (1995). Use of a free radical method to evaluate antioxidant activity. LWT - Food Science and Technology, 28(1), 25-30. https://doi.org/10.1016/S0023-6438(95)80008-5.

Buriol, L., Finger, D., Schmidt, E. M., Dos Santos, J. M. T., Da Rosa, M. R., Quináia, S. P., Torres, Y. R., Santa, H. S. D., Pessoa, C., De Moraes, M. O., CostaLotufo, L. V., Ferreira, P. M. P., Frankland Sawaya, A. C. H., \& Eberlin, M. N. (2009). Composição química e atividade biológica de extrato oleoso de própolis: Uma alternativa ao extrato etanólico. Quimica Nova, 32(2), 296-302. https://doi.org/10.1590/S0100-40422009000200006. 
Cadden, A. (1987). Comparative Effects of Particle Size Reduction on Physical Structure and Water Binding Properties of Several Plant Fibers. Journal of Food Science, 52(6), 1595-1599. https://doi.org/10.1111/j.1365-2621.1987.tb05886.x.

Colonna, P., Doublier, J. L., Melcion, J. P., Monredon, F., \& Mercier, C. (1984). Extrusion Cooking and Drum Drying of Wheat Starch. I. Physical and Macromolecular Modifications. In Cereal Chemistry, 61(6), 538-543.

Darvin, M. E., Gersonde, I., Albrecht, H., Meinke, M., Sterry, W., \& Lademann, J. (2006). Non-invasive in vivo detection of the carotenoid antioxidant substance lycopene in the human skin using the resonance Raman spectroscopy. Laser Physics Letters, 3(9), 460-463. https://doi.org/10.1002/lapl.200610032.

de Lanerolle, M. S., Buddhika Priyadarshani, A. M., Sumithraarachchi, D. B., \& Jansz, E. R. (2008). The carotenoids of Pouteria campechiana (Sinhala: Ratalawulu). Journal of the National Science Foundation of Sri Lanka, 36(1), 95-98. https://doi.org/10.4038/jnsfsr.v36i1.136.

El-Agamey, A., \& McGarvey, D. J. (2016). Peroxyl radical reactions with carotenoids in microemulsions: Influence of microemulsion composition and the nature of peroxyl radical precursor. Free Radical Biology and Medicine, 90, 75-84. https://doi.org/10.1016/j.freeradbiomed.2015.10.427.

Guillon, F., \& Champ, M. (2000). Structural and physical properties of dietary fibres, and consequences of processing on human physiology. Food Research International, 33(3-4), 233-245. https://doi.org/10.1016/S0963-9969(00)00038-7.

Gülçin, I. (2010). Antioxidant properties of resveratrol: A structure-activity insight. Innovative Food Science and Emerging Technologies, 11(1), 210-218. https://doi.org/10.1016/j.ifset.2009.07.002.

Heredia-Guerrero, J. A., BenÃ-tez, J. J., DomÃ-nguez, E., Bayer, I. S., Cingolani, R., Athanassiou, A., \& Heredia, A. (2014). Infrared and Raman spectroscopic features of plant cuticles: a review. Frontiers in Plant Science, 5. https://doi.org/10.3389/fpls.2014.00305.

Iqbal, M., Saeed, A., \& Zafar, S. I. (2009). FTIR spectrophotometry, kinetics and adsorption isotherms modeling, ion exchange, and EDX analysis for understanding the mechanism of $\mathrm{Cd}^{2+}$ and $\mathrm{Pb}^{2+}$ removal by mango peel waste. Journal of Hazardous Materials, 164(1), 161-171. https://doi.org/10.1016/j.jhazmat.2008.07.141.

Kalt, W. (2005). Effects of Production and Processing Factors on Major Fruit and Vegetable Antioxidants. Journal of Food Science, 70(1), R11-R19. https://doi.org/10.1111/j.1365-2621.2005.tb09053.x.

Kaur, M., \& Singh, N. (2005). Studies on functional, thermal and pasting properties of flours from different chickpea (Cicer arietinum L.) cultivars. Food Chemistry, 91(3), 403-411. https://doi.org/10.1016/j.foodchem.2004.06.015.

Kong, K. W., Khoo, H. E., Prasad, N. K., Chew, L. Y., \& Amin, I. (2013). Total phenolics and antioxidant activities of Pouteria campechiana fruit parts. Sains Malaysiana, 42(2), 123-127.

Lin, M. J. Y., Humbert, E. S., \& Sosulski, F. W. (1974). Certain functional properties of sunflower meal products. Journal of Food Science, 39(2), 368-370. https://doi.org/10.1111/j.1365-2621.1974.tb02896.x.

Ma, J., Yang, H., Basile, M. J., \& Kennelly, E. J. (2004). Analysis of polyphenolic antioxidants from the fruits of three Pouteria species by selected ion monitoring liquid chromatography-mass spectrometry. Journal of Agricultural and Food Chemistry, 52(19), 5873-5878. https://doi.org/10.1021/jf049950k.

Mothé, C. G., \& De Miranda, I. C. (2009). Characterization of sugarcane and coconut fibers by thermal analysis and FTIR. Journal of Thermal Analysis and Calorimetry, 97(2), 661-665. https://doi.org/10.1007/s10973-009-0346-3.

Murillo, E., Meléndez-Martínez, A. J., \& Portugal, F. (2010). Screening of vegetables and fruits from Panama for rich sources of lutein and zeaxanthin. Food Chemistry, 122(1), 167-172. https://doi.org/10.1016/j.foodchem.2010.02.034.

Olsson, A. M., \& Salmén, L. (2004). The association of water to cellulose and hemicellulose in paper examined by FTIR spectroscopy. Carbohydrate Research, 339(4), 813-818. https://doi.org/10.1016/j.carres.2004.01.005.

Posé, S., Kirby, A. R., Mercado, J. A., Morris, V. J., \& Quesada, M. A. (2012). Structural characterization of cell wall pectin fractions in ripe strawberry fruits using AFM. Carbohydrate Polymers, 88(3), 882-890. https://doi.org/10.1016/j.carbpol.2012.01.029.

Pushpakumara, D. K. N. G. (2007). Lavulu Pouteria campechiana Kunth Baehni. In D. K. N. G. Pushpakumara, H. P. M. Gunasena, \& V. P. Singh (Eds.), Underutilized fruit trees in Sri Lanka (pp. 426-436). World Agroforestry Centre.

Rodrigues-Amaya, D. B., Kimura, M., \& Amaya-Farfan, J. (2008). Fontes brasileiras de carotenóides: tabela brasileira de composição de carotenóides em alimentos (Coradin, L., \& Pombo, V. B. (eds.)). MMA/SBF.

Rodriguez-Amaya, D., \& Kimura, M. (2004). HarvestPlus Handbook for Carotenoid Analysis. HarvestPlus Technical Monographs, 59.

Rufino, S. M., Alves, R. E., Brito, E. S. De, Pérez-Jiménez, J., Saura-Calixto, F., \& Mancini-filho, J. (2010). Bioactive compounds and antioxidant capacities of 18 non-traditional tropical fruits from Brazil. Food Chemistry, 121(4), 996-1002. https://doi.org/10.1016/j.foodchem.2010.01.037.

Schwartz, S. J., von Elbee, J. H., \& Monica Giusti, M. (2007). Colorants. In S. Damodaran, K. L. Parkin, \& O. R. Fennema (Eds.), Fennema's food chemistry, 445-498. CRC Press.

Singleton, V. L., Rossi Jr., J. A., \& Rossi J A Jr. (1965). Colorimetry of Total Phenolics with Phosphomolybdic-Phosphotungstic Acid Reagents. American Journal of Enology and Viticulture, 16(3), 144-158. https://doi.org/10.12691/ijebb-2-1-5.

Stehfest, K., Toepel, J., \& Wilhelm, C. (2005). The application of micro-FTIR spectroscopy to analyze nutrient stress-related changes in biomass composition of phytoplankton algae. Plant Physiology and Biochemistry, 43(7), 717-726. https://doi.org/10.1016/j.plaphy.2005.07.001. 
Research, Society and Development, v. 10, n. 1, e16410111577, 2021

(CC BY 4.0) | ISSN 2525-3409 | DOI: http://dx.doi.org/10.33448/rsd-v10i1.11577

Stuart, B. H. (2004). Infrared Spectroscopy: Fundamentals and Applications. In Infrared Spectroscopy: Fundamentals and Applications. John Wiley \& Sons, Ltd. https://doi.org/10.1002/0470011149.

Sunila, A. V, Kumar, V. S. A., Babu, K. V. D., \& Murugan, K. (2016). Comparison of FTIR fingerprints in the fruits of Pouteria campechiana (Kunth) Baehni at different developmental stages. International Journal of Pure and Applied Bioscience, 4(1), 226-234.

Wojciechowski, C., Dupu, N., Ta, C. D., Huvenneb, O. J. P., \& Legrandb, P. (1998). Quantitative analysis of water-soluble vitamins by ATR-FTIR spectroscopy. 63(1).

Wojdyło, A., Figiel, A., Lech, K., Nowicka, P., \& Oszmiański, J. (2014). Effect of Convective and Vacuum-Microwave Drying on the Bioactive Compounds, Color, and Antioxidant Capacity of Sour Cherries. Food and Bioprocess Technology, 7(3), 829-841. https://doi.org/10.1007/s11947-013-1130-8.

Zhu, Q. Y., Hackman, R. M., Ensunsa, J. L., Holt, R. R., \& Keen, C. L. (2002). Antioxidative activities of oolong tea. Journal of Agricultural and Food Chemistry, 50(23), 6929-6934. https://doi.org/10.1021/jf0206163. 